\title{
Rehabilitation in Principle and Practice: Perspectives of Inmates and Officers
}

\author{
YANIQUE A. ANDERSON AND LINDA GRÖNING *
}

\section{Introduction}

Crime prevention is understood as a central legal aim of the Norwegian criminal justice system. One conceivable way of achieving this objective is by focusing on the rehabilitation of current inmates. However, it is not always clear what rehabilitation amounts to, or whether it is understood and implemented in accordance with legal intentions, especially since the selected methods by which to achieve rehabilitation may differ. It is therefore imperative to examine both the aims and practices of rehabilitation, and to be aware of any variance between the two. Doing so allows us to evaluate whether the legal aims of rehabilitation are actually being implemented in practice.

In this article the authors consider how inmates and those working within the Norwegian Correction Services perceive the concept of rehabilitation. More specifically, the

* Yanique Anderson is the recipient of a Fulbright research grant to Norway and a guest student at the Faculty of Law, University of Bergen. Linda Gröning is a professor at the Faculty of Law, University of Bergen, doing research within the project 'The Functionality of the Criminal Justice System', which is funded by the Bergen Research Council. She has also a research position at the Regional Centre for Research and Education in Forensic Psychiatry and Psychology, Haukeland University Hospital, Bergen. The authors would like to thank the U.S.-Norway Fulbright Foundation for Educational Exchange and the Bergen Research Council for financially supporting the research, and the University of Bergen Faculty of Law, Rachael Barlow, Kristian Mjåland, Kamilla Gade and the administrators at the studied prison for their invaluable contribution to the completion of this project. The authors would also like to thank the anonymous reviewer for comments and suggestions. 
authors focus on rehabilitation in practice as it relates to services and programmes for inmates in a select Norwegian prison, here referred to as 'Viken Prison'. ${ }^{1}$ The discussions that follow are centred on an interview-based pilot study conducted by Yanique Anderson, in Viken Prison. ${ }^{2}$ The aim of the study was to understand inmates and officers' view of rehabilitation, and to understand the structural and organisational procedures through which inmates access and utilise various kinds of rehabilitative support offered to them. The study was hence guided by the central question: What does rehabilitation look like from the perspective of inmates and prison officers, respectively?

Through the article, we do not suppose that the findings from the study are representative of the Norwegian prison system as a whole, or that it necessarily provides a complete picture of the day-to-day practicalities of rehabilitation in Viken prison. However, the findings highlight concerns about what rehabilitation in prison could and should entail. After all, the attitudes and opinions of those directly affected by rehabilitative work must be centrally considered. ${ }^{3}$ By presenting and discussing our findings, we hope that our article will generate more deliberative dialogue, and stimulate further research in this area.

\section{Rehabilitation in Prison: Theoretical and Legal Framework}

\subsection{Approaches to Rehabilitation}

The concept and meaning of rehabilitation is subject to debate. Literature in different disciplines outline a large number of different theories, positions, models and approaches to rehabilitation. Such models include the risk-need-responsivity (RNR) model and the good lives model (GLM). Within RNR, 'the risk principle speaks of who should be treated (the higher risk offender), the need principle speaks to what should be treated (criminogenic needs) and the responsivity principle helps determine how to treat. ${ }^{4}$ Conversely, GLM is a strength-based approach that 'focuses on promoting individuals' important personal goals,

1 The name and location of the prison have been withheld for ethical considerations.

2 This study was conducted under the supervision of Linda Gröning.

3 See also Kolstad, Imprisonment as Rehabilitation: Offenders' Assessment of Why it Does Not Work, Journal of Criminal Justice (1996) pp. 323-335 at 325.

4 Bonta and Andrews, Risk-need-responsivity model for offender assessment and rehabilitation, Rehabilitation 6 (2007): pp. 1-22. 
while reducing and managing their risk for future offending. ${ }^{5}$ The controversies concern both the understanding and conceptualisation of rehabilitation, and the adequate strategies to realise it effectively. ${ }^{6}$

In this study, it was not our primary intention to take a stand in these debates. Our focus was on revealing how rehabilitation is understood by the inmates and the officers in Viken Prison. Therefore we started from a sufficiently 'open' account of rehabilitation that provided room for different views among those being interviewed. As a starting point for the interviews, therefore, 'rehabilitation' was identified as any discourse or practice that speaks to transforming or normalising the criminal into a socially defined non-deviant citizen. ${ }^{7}$ Generally, it may include many different actions, such as psychological programmes (i.e. counselling or psychotherapy), interpersonal or situational assistance (i.e. through family interventions, training, and education), structural assistance (i.e. through employment or housing interventions), or some combination (placement in residential therapeutic programmes). ${ }^{8}$ It may also be considered as both an individual and a social project, and may relate to many different psychological, moral, sociological and legal issues.

Although we started from a sufficiently open definition, the interviews took place within, and will be discussed in relation to the specific legal aim of rehabilitation in the Norwegian criminal justice system. This legal framework will now be further clarified.

\subsection{Premise in Law}

The aims of rehabilitation are an integral part of the Norwegian penal and legal policies, and are explicitly expressed in official Norwegian legal documents. On the basis of these documents it becomes clear that rehabilitation is understood and implemented in relation to crime prevention as the (central) aim of punishment. ${ }^{9}$

5 Whitehead, Ward and Collie, Time for a change: Applying the Good Lives Model of Rehabilitation to a High-Risk Violent Offender, International Journal of Offender Therapy and Comparative Criminology (2007) pp. 578-598. For a detailed discussion on GLM, see Ward and Brown, The Good Lives Model and Conceptual Issues in Offender Rehabilitation, Psychology, Crime \& Law (2004) pp. 243-257.

$6 \quad$ For an overview and discussion of central perspectives, see McNeill, Four forms of 'offender' rehabilitation: towards an interdisciplinary perspective, Legal and Criminological Psychology (2012) pp. 1-19. See also Ward and Maruna, Rehabilitation (Routledge 2007) chap. 5-7.

7 This definition is used by Lynch, Rehabilitation as Rhetoric: The Ideal of Reformation in Contemporary Parole Discourse and Practices, Punishment \& Society 2, no. 1 (2000) pp. 40-65, at 45 .

$8 \quad$ Lynch 2000 p. 45.

9 See Ot.prp. nr. 90 (2003-2004) Om lov om straff (straffeloven) p. 77, for this account of the aim of punishment in Norwegian law. 
More specifically, the Execution of Sentences Act (hereinafter ESA) outlines the central rules for the administration of a prison sentence, with its supplementing directives and guidelines. ${ }^{10}$ ESA section 2 states inter alia that the sentence shall be executed in a manner that 'serves to prevent the commission of new criminal acts. ${ }^{11}$ It follows from various white papers (reports) from the Ministry of Justice that state that the crime-preventive work in prison is primarily related specifically to the inmates' rehabilitation and reintegration into society. ${ }^{12}$ The focus is on counteracting key crime-causing factors, such as unemployment and social exclusion. Accordingly, various forms of professional training, education and treatment are understood to be required within the prison system. ${ }^{13}$ An overarching aim of these different measures is to provide inmates with new knowledge and motivation for change, and to stimulate their resources to master a life without criminality. ${ }^{14}$

As a general principle, the Norwegian Correction Service stipulates that participation in rehabilitation programmes in prison must be voluntary. Before an inmate is offered participation in a programme, an evaluation is conducted to determine whether the programme is suitable for the inmate, in light of his or her risk-and-need profile and situation. ${ }^{15}$ This evaluation is based upon certain instruments that seek to implement different perspectives on and knowledge about rehabilitation. ${ }^{16}$

10 An English version of ESA is available at: http://www.kriminalomsorgen.no/the-executionof-sentences-act-in-six-languages.250423.no.html. (Accessed December 1, 2016). See further Storvik, Straffegjennomføring: etter lov av 18. mai 2001 nr. 21, 2. utg., (Høyskoleforlaget 2011) pp. 21-33 for an overview of the different rules and guidelines in this area.

11 The provision also underlines other aims; that 'a sentence shall be executed in a manner that takes into account the purpose of the sentence that serves to prevent the commission of new criminal acts, that reassures society, and that within this framework ensures satisfactory conditions for the inmates'. For a fuller explanation of this provision, see Gröning, Straffgenomföring som en del av straffrättssystemet: Principförklaring av fängelsestraffets innehåll, Tidsskrift for Rettsvitenskap no. 1-2, Vol. 126 (2013), pp. 145-196.

12 See St.meld. nr. 37 (2007-2008) Straff som virker - mindre kriminalitet - tryggere samfunn, chap. 9 and Ot.prp. nr. 5 (2000-2001) Om lov om gjennomføring av straff $m v$. (straffegjennomføringsloven) p. 98.

13 For an analysis of different forms of programmes and measures of rehabilitation, see Hollin and Palmer, Offending behavior programmes: Development, Application, and controversies. (John Wiley \& Sons Ltd 2006) chap. 1. Offending Behaviour Programmes: History and Development.

14 See St. Meld. Nr 37 (2007-2008) Straff som virker - mindre kriminalitet - tryggere samfunn, pp. 9-10.

15 See http://www.kriminalomsorgen.no/programvirksomhet.237975.no.html. (Accessed December 1, 2016).

16 For instance, the evaluation instrument, BRIK, integrates approaches such as the 'what works? tradition', desistance based theories, restorative justice approaches and motivational interviewing. BRIK, has been assessed in Dahl, Hansen and Samuelsen, EVALUERING AV BRIK - Behovs- og ressurskartlegging i kriminalomsorgen, research report 2014:2, Høgskolen i Østfold. 
Alongside the general statement in ESA article 2, rehabilitation, as an aim, is also reflected through several other rules of the ESA. ESA section 18 states that the Correctional Services shall arrange for inmates to be provided facilities for activities during daytime, which may amount to work, training, programmes or other measures designed to counteract the development of further criminal behaviour. In this regard, inmates only have an obligation to work in prison, while other kinds of activities and measures as described above are voluntary. Activities such as education shall be available to all inmates because they are considered both a constitutional and human right. ESA section 4 states that the Norwegian Correctional Services shall, by engaging in cooperation with other public services, arrange for the inmates to receive the services to which they are statutorily entitled. ${ }^{17}$

ESA also makes provisions for inmate activity in programmes located outside the prison. ESA section 20 states that the Correctional Services may grant inmates permission to participate in work, training, programmes or other activities outside prison if security reasons do not contraindicate this, and if there is no reason to assume that inmates will evade the execution of their sentences.

Further, the aim of rehabilitation relates to the implementation of the central principles of normality and the progression towards reintegration. The normality principle, in essence, means that the deprivation of liberty is regarded as punishment, and no inmate shall serve their sentence under conditions stricter than is necessary for the safety of the community. It also stipulates that the time in prison for inmates should be as 'normal' as possible when it comes to daily working routines, education and activities within the prison. ${ }^{18}$ In addition, opportunities for inmates to participate in leisure activities shall be provided, as far as possible, which is also reflected in ESA section 21. The principle of progression means that there should, as far as possible, be a gradual transition from imprisonment to complete freedom. ${ }^{19}$

Even though rehabilitation is a clear legal aim, there are some constraints on its realisation within the prison. Imprisonment is the restriction of personal freedom. It entails a more or less comprehensive and prolonged external limitation of the inmate's opportunity to live and function freely. ${ }^{20}$ Therefore, there are some inherent limits to what rehabil-

17 For a discussion about how the Import-model in Norway can be a useful tool in bringing different agencies together in the rehabilitation process, see Langelid, The Sharing of Responsibility in the Rehabilitation of prisoners in Norway: the Import model in Theory and Practice, Journal of Correctional Education (1999) pp. 52-61.

18 See NOU 1988:37, pp. 48-50 and St. meld. 37 (2007-2008) p. 22. See further Vollan, Mot normalt? Normalitetsprinsippet i norsk straffgjennomføring in Lov, liv og loere. Festskrift til Inge Lorange Backer, eds. Bugge et al., (Universitetsforlaget 2016) pp. 548-560.

19 See Ot.prp. nr 5 (2000-2001) pp. 68 and 140.

$20 \quad$ Cf.. NOU 1988:37 Ny fengselslov p. 49. 
itation can amount to. ${ }^{21}$ The rules that regulate different kinds of rehabilitative activities are also, in general, conditioned by the possibility of carrying these out in a safe manner. More generally, the aim of crime prevention provides for a focus on rehabilitation as a means for securing the public from future crimes, with the possible risk of not taking the interests of the inmate seriously. ${ }^{22}$

Furthermore, it is a fact that the idea of rehabilitation for inmates is sometimes argued to be in tension with the entire concept of punishment. Traditionally, 'punishment' in Norway is understood as an 'evil' imposed on an individual as a reaction to a criminal act. ${ }^{23}$ Obviously this conception of punishment stands in contrast to the notion that inmates should be able to enjoy certain benefits in their best interests as part of their rehabilitation. It also shows that dialogue on the concept of punishment is an important part of the discussion on rehabilitation in prison. ${ }^{24}$

In our view, such a discussion must recall the fundamental constitutional principles of individual freedom, dignity and equality - the very ideological foundations of the democratic state under the rule of law. As a part of the legal order, the execution of a prison sentence is also subject to these legal and ethical standards that provide guidance for an understanding of the overarching nature and purpose of the punishment. ${ }^{25}$ They also provide guidance for the way the punishment is to be administered-including rehabilitation within the prison sentence.

This principled account underlines rehabilitation as not only a social project, although it requires social inclusion of the individual as a member of the group. First and foremost it must be based on an individual moral project that cannot and should not be forced on a person, but that can be facilitated legally and practically. The principle of voluntary

21 It is also often questioned whether rehabilitation can at all be realised in a prison context. See Kolstad 1996, pp. 323-335 for a relevant study in this regard. For a study that indicates more positive results of rehabilitation in Norwegian prisons, see Bhuller et al., Incarceration, Recidivism and Employment, working paper in Economics 7/16, Department of Economics, University of Bergen, available at http://www.uib.no/sites/w3.uib.no/files/attachments/working_paper_07-16. pdf. (Accessed December 1, 2016).

22 An alternative approach may, however, be a more deontological perspective to rehabilitation, as a matter of restoring, and thereby reintegrating, the inmate as a responsible citizen with certain rights and duties - and in this way eventually promoting the aim of crime prevention. See further on this distinction in McNeill, Four forms of 'offender' rehabilitation: towards an interdisciplinary perspective, Legal and Criminological Psychology (2012) pp. 1-19, p. 5.

23 Seefor this account on punishment Andenæs, Statsforfatningen i Norge, 9. utg.(Universitetsforlaget 2004), p. 326 and Rt. 1977 s. 1207.

24 For a further discussion on the concept of punishment and imprisonment, see Gröning 2013 pp. 159-160.

25 For a further explanation of this constitutional fundament of the Norwegian criminal justice system, see Gröning et al., Frihet, forbrytelse og straff-En systematisk fremstilling av norsk strafferett (Fagbokforlaget 2016) chap. 2. 
rehabilitation in the Norwegian system is therefore of great significance. The principled account further emphasises that rehabilitation within the prison context must be equally accessible to all, and should not be discriminatory, when it comes to what is offered and to whom. In the end, it underlines human dignity as the meta-norm for thinking about and implementing rehabilitation in prison, taking the interests and views of the inmates about their own (needs for) rehabilitation seriously.

\subsection{Examining 'Scandinavian Exceptionalism' as a Context for Rehabilitation}

In international discussion, the Norwegian and Scandinavian prison conditions have many times been described as exceptionally humane. ${ }^{26}$ The notion of 'Scandinavian Exceptionalism' has in this context been used with regard to the fact that Scandinavian countries have a low level of repression, low imprisonment rates and humane prison conditions. $^{27}$

This picture of the Scandinavian countries is in certain aspects correct, in particular when focusing on the general criminal policy and the content of the criminal law. As described above, the legal aims and policies concerning rehabilitation also reflect humanistic values.

However, this does not necessarily tell us all about the concrete situation and practices within Norwegian prisons-nor does it account for variance, depending on the specific prison culture. ${ }^{28}$ Further, in a broader sense, imprisonment should be examined in the larger context, to include social, historical and cultural discourses and practices. For inmates more specifically, imprisonment should be examined in relation to the additional factors that impact their experiences and extend beyond prison conditions. ${ }^{29}$

As a case in point, in recent years, Norway has witnessed developments that challenge the upholding of a humane criminal justice policy. Although the ESA principles

26 See for an overview Johnsen et al., Exceptional Prison conditions and the quality of prison life: Prison size and prison culture in Norwegian closed prisons, European Journal of Criminology (2011) pp. 515-529 at 515-516.

27 See inter alia, Pratt, Scandinavian Exceptionalism in an Era of Penal Access. Part I: The Nature and Roots of Scandinavian Exceptionalism, British Journal of Criminology (2008) pp. 119137, Pratt and Erikson, Scandinavian Exceptionalism in Criminal Policy, Nordisk tidskrift for kriminalvidenskap (2009) pp. 135-151 and Ugelvik and Dullum (eds), Penal Exceptionalism? Nordic Prison Policy and Practice (Routledge 2011) pp. 1-10.

28 For a study that shows that the quality of prison life may vary depending on the size of the prison, see Johnsen et al. 2011 pp. 515-516.

29 For a discussion of prison conditions and the resulting pains relative to the wider historical, and socio-cultural context, see Neumann, Imprisoning the Soul in Penal Exceptionalism? Nordic Prison Policy and Practice, eds. Dullum and Ugelvik (Routledge 2012) pp. 139-151. 
discussed above still remain, the Norwegian penal system has become arguably more punitive, adopting a 'law and order' rhetoric that has in some sense destabilised what has long been considered the norm. ${ }^{30}$ The number of prison sentences has increased and, with them, capacity problems and a substantial workload for the prison officers. Most notable also, the economic situation has become worse. Altogether, these factors may promote, and explain, harsher criminal justice policies.

A specific and growing problem regards the foreign inmates who do not have a residence permit in Norway. ${ }^{31}$ This problem is reflected in the fact that Norway has established a special prison unit for foreign prisoners, Kongsvinger Prison, that houses male inmates who are to be deported from Norway upon their release or who are to be transferred to serve their sentence in their home country. ${ }^{32}$ In this regard, the capacity-related problems are also reflected in the fact that Norway rents prison spaces in Norgerhaven Prison in the Netherlands. ${ }^{33}$

In the case of Viken Prison, as we will return to, some inmates face a number of challenges related to mental health and drug abuse. These in turn pose particular logistical challenges that require additional resources from the prison.

While we recognise that the increased incarceration rates in Norway are occurring at a lower pace than its Western European neighbours, we acknowledge (as in the case with Viken prison) that deprivations do exist, however 'unusual' or obscure they may seem..$^{34}$ Therefore, with regard to the specific aim of rehabilitation, one must be careful of drawing too heavily on the concept of 'Scandinavian Exceptionalism. The legal ideals of rehabilitation are quite clear and are expressions of an adequate humanistic outlook, however they tell us little about what rehabilitation amounts to in practice and how it is viewed among inmates and officers. ${ }^{35}$ As was clear by the study that will now be presented, the prison officers have to a large extent adopted the legal ideals of rehabilitation, but

30 For a discussion on the rise of punitive policies in Norway, see Shammas, The Rise of a More Punitive State: On the Attenuation of Norwegian Penal Exceptionalism in an Era of Welfare State Transformation, Journal of Critical Criminology (2016) pp. 57-74.

31 For a discussion of the non-discrimination principle in the prison context, see Gröning, Education for foreign inmates in Norwegian prisons: A legal and humanitarian perspective, Bergen Journal of Criminal Law and Criminal Justice 2 (2) (2014) pp. 164-188.

32 For further information on this prison, see Visit Report from the Parliamentary ombudsman in Norway, pp. 25-27 August 2015, available at https:/www.sivilombudsmannen.no/getfile. php/Rapporter/150825\%20Visit\%20report\%20Kongsvinger\%20prison\%20EN\%20final.pdf. (Accessed December 1, 2016)

33 See further information on this prison at http://www.kriminalomsorgen.no/norgerhavenfengsel-nederland.5777803-237612.html. (Accessed December 1, 2016).

34 See Shammas, The Rise of a More Punitive State: On the Attenuation of Norwegian Penal Exceptionalism in an Era of Welfare State Transformation, Journal of Critical Criminology (2016) pp. 57-74.

35 For a critique on the 'exceptionalism' theory, see Ugelvik and Dullum 2012 pp. 1-10. 
at the same time struggle with the implementation. Further, interestingly enough, the views of the inmates in many aspects seem to oppose the views of the officers on what rehabilitation is about and for whom it works.

\section{The Study}

\subsection{The Prison Setting}

The Norwegian penitentiary system is comprised of prison institutions of varying security levels. Inmates serve their sentences in prisons with a high security level (closed prisons) or a lower security level (open prisons). ${ }^{36}$ In high security prisons there is typically a strict regime; the inmates spend many hours in their cells and are constantly under strict supervision. In prisons with lower security, the inmates spend more time in the community with others and have more freedom. ${ }^{37}$ The prisons' security systems have, as we shall see, a large practical impact on the possibilities of rehabilitation in prison.

The research site, Viken Prison, is a co-ed prison comprised of several sections-a closed high security prison and an open low security prison. The prison has multiple wings, from Wing-One that has the strictest regime, to Wing-Six that is less restrictive. In accordance with the principle of progression, inmates at Viken Prison would serve their sentence in steps or stages-by moving from more restrictive wings to less restrictive wings over time-based on their progress, until their eventual release. The inmates would start in Wing One, and then move from there into other wings that provide more programmes, activities and freedom. ${ }^{38}$

More concretely, Viken Prison provides resources and services such as education and work programmes, as well as specialised programmes targeting sexual offenders, drug abusers and violent offenders. The prison also works closely with external clinics to facilitate the medical and psychological needs of inmates. The concept of 'dynamic security' is also a key element. It emphasises the importance of establishing and maintaining a good relationship with inmates (for security and rehabilitative reasons) and officers treating inmates with empathy and respect. ${ }^{39}$ There is also a chapel that offers services and pro-

36 See ESA section 10.

37 In Norway there are also possibilities to serve prison sentences for less serious crimes at home with electronic foot-chain. See ESA section 16.

38 See also ESA section 11.

39 On the meaning of dynamic security, see Mjåland and Lundeberg, Penal Hybridization: StaffPrisoner Relationships In A Norwegian Drug Rehabilitation Unit in Juridification and Social Citizenship in the Welfare State (Edward Elgar Publishing Limited 2014) pp. 183-202. 
grammes such as occasional outings. Lastly, there are volunteer-based programmes and services available from outside organisations such as the Red Cross.

The officers' roles are generally the same throughout the prison, in that they are expected to maintain contact with the inmates and treat them with respect and care. Many prison officers are also assigned a special role in facilitating the rehabilitation of offenders, particularly through the establishment of the 'contact service' arrangement. Through this arrangement, every inmate should have a personal contact officer who is supposed to motivate and assist him or her in the process of rehabilitation. In addition, a contact officer is typically responsible for counselling a total of four to ten designated inmates; and the officer has an important role in helping inmates in their communication and cooperation with outside welfare agencies, as well as helping the inmate with other problems and requests during their imprisonment. ${ }^{40}$ For these reasons, prison officers are influential and are in many respects, the most important gatekeepers for a wide range of rehabilitation services. ${ }^{41}$

\subsection{Method of Study: Data Collection and Analysis}

The study was exploratory in design and employed a qualitative methodology. The primary source of data collection was through the use of semi-structured interviews with inmates and officers at Viken Prison. For this project, a total of 20 inmates as well as 11 officers were interviewed between February and March 2016.

Inmates and officers were selected using convenience sampling. Inmate sampling was limited to three wings in Viken prison. Officers, on the other hand, were selected from all wings except one, where there were no volunteers. The initial goal was to interview inmates and officers from all areas of Viken Prison, however time and capacity challenges limited the scope of the project.

Information flyers in Norwegian and English were created to facilitate the recruiting process. These flyers were sent to the first officers of each wing in advance. From there, the first officer would inform the officers of the project and, if interested, the officers could volunteer to participate. For the inmates, the officers would give some information about the project, and those interested could contact an officer or the senior officer of their wing, who would then put their names on a voluntary interview list. After the list of names was compiled, the senior officer would determine a date and time in which interviews could be conducted without disrupting the daily schedules of the inmates, and

$40 \quad$ Johnsen et al. 2011 p. 517.

$41 \quad$ Mjåland and Lundeberg 2014 pp. 184-185. 
a time that would work best for the officers. If there were any unforeseen circumstances, the interviews would be rescheduled.

Though co-ed, the prison is predominantly male and in the end, all the inmate participants were male, whereas the officers were a combination of males and females. Fifteen of the inmate participants were native Norwegian, and five were from a foreign country. All of the interviews with officers were conducted in English. For inmate participants, however, the service of an interpreter was provided to those who did not feel comfortable speaking English.

Before the start of each interview, participants were given information sheets. The sheets were available in either English or Norwegian and were distributed based on language preference. Each sheet highlighted a few key points: voluntary participation, the absence of penalty if the participant decided to withdraw from the study, an assurance of data confidentiality if quotes were used in the published article, and the right to decline to answer any questions that they preferred not to answer. These points were reiterated verbally, to ensure clarity. Participants were given the opportunity to ask further questions before they were presented with a consent form. If the participants were comfortable with these stipulations, they would then receive a consent form to sign.

The interviews were semi-structured with open-ended questions related to issues of care and confinement, with particular focus on rehabilitation and the impact of rehabilitation programmes and services on inmates in Viken Prison. Officers were not asked to disclose confidential information about inmates. There was no sensitive information obtained from any source other than the inmates themselves. To protect the identities of the participants, the interviews were not recorded. Instead, detailed field notes and jottings were taken.

The jottings and field notes from each interview were translated and completed after the interviews and each note was saved as a separate Microsoft Word document. Analysis of the data began with close readings of each transcription to develop a preliminary coding scheme. Subsequent readings of the transcriptions resulted in the development of final codes throughout which the data was further simplified. From there, emerging themes were noted from the analysis of each transcription. Similarities and differences emerging from a comparison between cases were also noted. ${ }^{42}$

Some limitations following from the study should be noted. First, there may be an element of self-selection bias following from the fact that the study was volunteer-based. Also, due to the sampling method and small sample size there were limitations on the generalizability of the results. In spite of these limitations, we note that the views and findings discussed are reflective of the participants and are not to be considered representative of the general population at Viken prison. Instead, the findings should be 
understood as revealing the different individual perspectives from inmates and officers.

\subsection{Approval}

This study was approved by the Norwegian Correctional Services (ref. 201510218-7) and the Norwegian Social Sciences Data Services (ref. 44449 / 3 / HIT).

\section{The Main Results of the Study}

\subsection{Overview}

The study revealed varying points about rehabilitation and related issues in Viken Prison. Out of those points, the more significant findings will be presented in the sections that follow. Starting with what is perhaps most central to this article, section 4.2 discusses how inmates and guards conceptualise rehabilitation. Sections 4.3-4.5 focus on the issues that inmates and officers identified as problematic because of their ability to either impact or hinder rehabilitation efforts. Those issues include: inmate isolation and mental health, inmate drug use, limited capacity and limited resources. Finally, section 4.6 presents the specific issue of unequal treatment as it pertains to bias and privilege between inmates, as well as programme opportunities and assistance for women and foreign immigrant inmates. The subject of unequal treatment was not an intended part of the study. However, the interviews revealed themes that seemed important to integrate into our discussion. All names of inmates and officers quoted in the findings below are pseudonyms. Also, to maintain participant confidentiality, the exact interview dates have not been cited.

\subsection{Rehabilitation Conceptualised}

In each interview, inmates were asked, 'How would you define rehabilitation?'. The answers to the question varied. Some inmates described rehabilitation as a way for them to live a crime-free life, whereas others felt that rehabilitation meant nothing to them, because they were not in need of it. Out of the 20 inmates, half of them described rehabilitation as a way by which one acquires the skills for adjusting and living a crime-free life within the community outside the prison. The remaining inmates described rehabilitation as being for a select group of inmates with select issues. When asked, 'Do you consider yourself in need of rehabilitation?' seven inmates said 'yes' and 13 inmates said 'no'. 
The seven inmates who answered ' $y e s$ ' believed that the rehabilitative process started in the prison and would continue on after their release. However, some expressed concerns as to what this process would look like in practice for them. For example, although they were willing to embrace the idea of rehabilitation, they did not feel any motivation to participate in things (such as activities) they felt they had little say in. One inmate articulated his feelings, saying, 'It's been boring... I am struggling with finding something meaningful. I am open for rehabilitation, but it has to be individualized and it cannot happen over your head (i.e. without inmate participation). ${ }^{43}$

The inmates with opposing views offered a wide range of explanations to supplement their reasoning. Some described Viken prison as 'storage' for humans and nothing more. Others insisted that their cases were different because they knew that what they did was wrong and they had accepted their punishment. This sense of penance was seen as central to their rehabilitation. Other inmates considered access to family assistance, housing and a job outside of prison as their rehabilitation ${ }^{44}$ and some inmates stated that rehabilitation was not a factor in their lives because they were wrongly imprisoned. During the interviews, some inmates stated that only people convicted of sexual abuse, violent or drug related crimes would be considered in need of rehabilitation. Some would also refer to inmates convicted of these specific crimes as 'those people'. Of particular note, some inmates made a point to (sometimes repeatedly) state why they did not see themselves in need of rehabilitation. As case in point, some inmates would use phrases such as, 'I don't have any problem [s]. I think I am a normal person' or 'There is nothing to fix if nothing is broken. Why fix what's not broken?'

One inmate who was convicted of a drug-related crime was particularly upset by the word 'rehabilitation' as he felt that it would strip him and others of their identity and autonomy by employing methods similar to those used in drug rehabilitation centres. Explaining his point, he said:

It's like basic psychological training - the same as they do in any rehab or other facilities... They want to tear you down then "build" you back up again as they see it. I would say that I am totally fine, but they would say that I am a drug addict and a violent man. ${ }^{45}$

Other inmates associated rehabilitation with a specific prison programme, thus concluding that the absence of a specialised programme targeting their individual issues

$43 \quad$ Simonsen, Rolf. Personal Interview. Viken Prison, March 2016.

$44 \quad$ Many inmates who already have these resources felt that they were not in need of any programmes and services while inside prison because they already had all they needed for a productive life outside of prison.

$45 \quad$ Steensen, Finn. Personal Interview. Viken Prison, February 2016. 
eliminated the overall need for rehabilitation. For example, Samir Thompson noted that he is only aware of three distinctive 'rehabilitative' programmes at Viken prison: a drug program, a violence programme and a sexual assault programme. Samir explained that he does not see himself in need of rehabilitation because of the absence of a programme designed for offenders convicted of his particular crime ${ }^{46} \mathrm{He}$ stated

...[For example], a violence programme won't help me; they don't have any programmes for people who have my sentence. They don't exist. If they had existed, I am not sure what they would be about. ${ }^{47}$

Overall, the inmates offered a broad range of analyses on rehabilitation as they see it for themselves and for others. Generally, in spite of their diverse conceptualisation of the word 'rehabilitation', many inmates used the words 'care' and 'help' repeatedly when describing their individual needs.

Like the inmates, the officers were also asked to state their definition of rehabilitation. The answers largely mentioned inmates living a 'better life' or a life without crime upon their release from prison. Some responses were more detailed and emphasised the importance of programmes and services in aiding the rehabilitative process. They also noted the importance of personal responsibility and motivation on the part of the inmates. When describing their roles in facilitating the rehabilitative process, the officers stressed the importance of personal interaction with the inmates. The officers also discussed their roles as officers and/or contact officers and, regardless of their position, stressed the importance of building and maintaining a positive relationship with the inmates. Though many remained largely positive, they did acknowledge several areas in which their efforts were less successful.

Discussing the relation between rehabilitation and the principle of progression, one officer explained the ways in which inmates' decisions to participate in (or opt out of) specialised programmes impacted their progression within the prison. When asked, Are any of the programmes obligatory?' the officer responded, 'No, you have to volunteer for every one of them'. However, this is not quite so, as the interviewer pointed out: 'In order to live in this wing, you have to be involved in something, right? So then, if the programmes are not obligatory, how does that work?' The officer responded, 'Yes. [For example] if you are a sex offender and you don't want to have the treatment you have to be on [another wing] but if you want to be on [this specific wing] you have to (emphasis added) do the therapy..$^{48}$ This answer calls for reflection on whether there is actually a pressure

\footnotetext{
46 The nature of Samir's crime has been withheld for ethical considerations.

$47 \quad$ Thompson, Samir. Personal Interview. Viken Prison, March 2016.

$48 \quad$ Salomon, Sam. Personal Interview. Viken Prison, February 2016.
} 
to participate, which is in opposition to the principles of voluntary participation in treatment programmes. ${ }^{49}$

Overall, officers stood firmly behind the concept of implementing humanistic principles expressed in law when dealing with offenders. For the officers, rehabilitation is a continual process for inmates that involves more than just programmes. They acknowledged that there are cases when people are incarcerated multiple times and only begin to seek after change after multiple arrests; and then there are cases when people are sent back to prison after making an effort and falling somewhere along the way. Still, they maintained that they do not give up on inmates, no matter the circumstances that led them back to prison, and that they would rather see an inmate return because he tried and, at some point, slipped back into bad habits, than to see an inmate who does not care about his or her own journey.

\subsection{Inmate Isolation and Mental Health}

When reflecting on rehabilitation, some of the inmates and officers pointed to the issues surrounding inmate isolation and mental health problems. Many of the concerns were directed at the conditions for inmates in Wing One. This is the unit where inmates generally start serving their prison sentence.

Giving context to the issue, one officer explained that Wing One has two units: One-A and One-B. On unit One-A, inmates are often held in isolation (sometimes because of a court order, sometimes not), and are only out of their cells for about two hours. Unit One-A allows for a bit more freedom, but is still considered restrictive when compared to the other wings of the prison. ${ }^{50}$ With such stringent restriction, Wing One is Viken Prison's strictest and most isolated unit. Some officers admitted that, because of this, inmates there do not have access to as many programmes, activities or opportunities as inmates in other wings, and thus officers do not regard Wing One as a rehabilitation wing.

When asked to describe the activities available to inmates on Wing One, one officer said, 'We don't have so much', explaining that there is a yard for fresh air, a garden, and the possibility to go to training one or two times per week. She added, 'We try to use it (the gym) but sometimes we don't have capacity to go there. The focus is on talking to them, trying to gauge their mood because it's not good to be locked up that long ${ }^{51}$

Commenting on mental health more specifically, another officer, Sam, explained that the risk for violence between officers and inmates is higher now than it was 10 years ago. Additionally, he said that the risk mostly stems from inmates that are mentally disturbed

\footnotetext{
49 See above in section 2 on the legal principles in this regard. See also section 5 for a discussion on these matters.

50 Andal, Kari. Personal Interview. Viken Prison, February 2016.

51 Vinter, Laila. Personal Interview. Viken Prison, February 2016.
} 
or are experiencing issues such as self-harm or stress from isolation. Officer Sam also said that the nature of the situation requires officers to place inmates with these problems as a top priority because officers have to 'take out the fire first before dealing with the other issues'. As long as the 'fire is ablaze', the other inmates on the wing (especially Wing One) will not get as much attention from the officers. As the number of inmates with mental health issues rise, additional concerns about how to confront the issue have also emerged. These inmates require both additional time and attention from the officers, and some also prefer to be in more secluded atmospheres, like that of Wing One. Therefore, while officers devote additional time and attention to a specialised group of inmates, the other inmates are put at an even further disadvantage.

Speaking on the lack of activity in Wing One, one inmate said, 'I had nothing to do, I was frustrated... I felt like it was half hospital, half kindergarten'.52 Another inmate described being so bored and lonely that he started talking to himself. This behaviour, he said was, 'normal for people in isolation'. He added, 'That's the way it is' ${ }^{53}$ When discussing isolation, some inmates stated that they wished to forget that part of their incarceration. Others would only speak about it briefly, just long enough to note their experience and displeasure at being held in isolation.

When asked about the structure of Wing One, one officer explained that Wing One was meant to be a temporary place for inmates. It was to be a place where inmates would be 'mapped' or examined in order to determine the best course of action regarding the rest of that inmate's stay in the prison. ${ }^{54}$ However, Wing One has not functioned in this capacity. Overall, rehabilitation opportunities are severely inhibited on Wing One for several reasons: compared to inmates from other Wings, inmates from Wing One have limited access to programmes and activities, and in general receive less stimulation than inmates in other wings. This prolonged isolation has impacted inmates' mood as expressed by feelings of boredom and frustration, which could perhaps also lead to further violent outbursts against officers, attempts at self-harm or to other acts of illicit activity for self-stimulation or to garner attention from officers. On the other hand, it can also cause inmates to be further withdrawn and distrusting of the officers who they may see as uncaring. Officers' jobs are also particularly difficult, as they must prioritise addressing and resolving issues such as violence and immediate mental health concerns over the needs of the other inmates, and must perform these duties while also ensuring the safety of the inmates as well as themselves. Finally, the fact that officers do not regard Wing One as a rehabilitation wing is also indicative the state of affairs at Wing One.

\footnotetext{
52 Abrahamsen, Mauricio. Personal Interview. Viken Prison, February 2016.

53 Arnesen, Cain. Personal Interview. Viken Prison, March 2016.

$54 \quad$ Hansen, Bjarne. Personal Interview. Viken Prison, March 2016.
} 
Although these discussions were generally focused on Wing One, two inmates in particular chose to speak about mental health concerns beyond this Wing. Using their own stories, they explained the difficulties some inmates (like themselves) have coping with their imprisonment because of their mental health issues. While discussing the role of mental health services in their sentence (in the form of sessions with a psychologist), both inmates attributed their sessions with a psychologist as instrumental to their rehabilitation, in terms of learning how to cope with their illnesses as well as helping them to develop better communication and interpersonal skills. For these inmates, mental health care has become part of their structure, and so there is discontent whenever they feel they cannot access the mental health services they require. For example, one inmate described being disappointed and forsaken after his psychiatric sessions were ended prematurely. When asked why his sessions ended, he attributed it to the lack of prison resources. In other words, he pointed to resource problems that we will return to later.

\subsection{Inmate Drug Use}

During interviews, inmates revealed the prevalence of drug abuse in Viken Prisonexpressing that inmates with drug issues still find ways to access drugs and that some inmates with no (known) prior drug history experiment with drugs and subsequently become addicted while in prison. For these reasons, some inmates identified drugs as having a negative presence and influence within the wings.

Inmates identified the main drugs of choice as the synthetic opioids, Methadone and Subutex, which are provided by the prison to inmates with opioid dependency or addiction as part of an effort to entirely discontinue opioid use. Inmates described these drugs as being another form of heroin, or even worse. They also stated that these drugs are being shared among inmates. Commenting on the issue, one inmate said, 'They (the officers) have to give less of this Subutex shit and give the Subutex in a way that they (the inmates) can't share it with others because this is the big problem in this prison'. ${ }^{55}$ Officers also confirmed the existence of a drug issue in Viken Prison, and explained the methods they implement in an effort to mitigate the problem. ${ }^{56}$

Some officers identified inmates with drug addiction issues as being particularly challenging or impossible to rehabilitate. When officers were asked, 'do you think most of the inmates on this wing have a good chance of being rehabilitated?' The answers would

55 Carlson, Lars. Personal Interview. Viken Prison, March 2016.

56 For a study on drug use, supply and exchange in a Norwegian prison, see Mjåland, A Culture of Sharing: Drug Exchange in a Norwegian Prison, Punishment \& Society (2014) pp. 336-352. See also Mjåland, The Paradox of Control: An Ethnographic Analysis of Opiate Maintenance Treatment in a Norwegian Prison, International Journal of Drug Policy (2015) pp. 781-789. 
differ based on the wing. Officers on Wing One would say, 'No' because they maintained that the Wing is not meant to be a place for rehabilitation. Officers on other wings would say, 'Yes' if the inmate is motivated to make a change. However, there was usually some hesitation when discussing drug offenders, as expressed by an officer:

Do you think many of the inmates on this wing have a good chance of being rehabilitated?

Those with drug related crimes will never be rehabilitated, they will always come back... many of them.

Why do you think that happens? When they are addicted, it's kind of a disease for them. It's so difficult to treat, so for many of them there is no cure for it.

When asked, 'What's being done to help them?' The officer explained that there is only one programme available called NSAP (National Substance Abuse Programme) and it only serves about 12 inmates per year. The problem, she says, is that 'we have more than 12 drug abusers a year here, so it's not covering it. ${ }^{57}$

From this we see several problematic issues: Viken prison's substance abuse programme does not adequately serve the needs of inmates with drug addiction; the presence of drugs on Viken prison's wings may also incentivise active drug users to continue using drugs; and the distribution of drugs within the wings may also pose a threat recovering drug addicts as well as inmates with no known prior drug history, who may become addicted as a result of experimentation. We should also note that inmates caught using drugs at Viken Prison face further repercussions, such as being removed from their less secure wings and being sent back to Wing One, where they are then faced with issues of isolation as discussed in sub-section 4.3.

\subsection{Limited Capacity and Resources}

During the interviews, both inmates and officers expressed concerns about the limited resources. The inmates' focus was mostly on resource scarcity and its role in their decreased motivation to participate in some of the activities or to ask for help. Officers discussed how limited capacity and limited resources have affected their ability to 
interact with inmates and also fulfil their administrative duties.

Addressing the resource scarcity issue, one inmate described what he perceived to be 'a huge lack of [resources] and personnel.'.$^{58}$ According to the inmate, resource scarcity has led to Viken Prison enlisting the services of, what he has called, 'untrained substitutes' because 'they don't have the money to use [more] trained officers'. He went on to say that Viken Prison needs 'some more staff to get things through [because] it's just too slow. It's not like how it's supposed to be... ${ }^{59}$ Speaking on the value of prison programmes, he said,

If you put money [into the prison], you don't get profit in money. This is not a bank, but the profits will come after some time when people are correctly rehabilitated, you will see it in society when they don't do crime [and] when they believe that they can live a life without crime, drugs and alcohol. ${ }^{60}$

One inmate, Jarle, suggested that inmates do not feel motivated to ask for help when they need it because they do not want to be disappointed. Speaking generally, he said:

It's a system with unfriendly guards... You need something in the living unit, [you ask for it and the guards say] "I'm busy; I don't have time; talk to the people in the evening. [When you ask later] they say, "I'm busy." You ask the next day and they say, "I'm busy". 61

Most officers often admitted that they are aware of the inmates' concerns. In terms of timeliness and interaction with inmates, a candid conversation with an officer revealed the following:

What is the biggest complaint from inmates?

I think they feel that we don't have enough time for them.

How do you feel about them saying that?

The same. Sometimes the inmates want to talk or do stuff but I can't because I'm too busy (emphasis added). Earlier, an inmate invited me to have coffee with him and I had to say "no" because I don't have time. ${ }^{62}$

58 Samir Thompson Interview.

59 Ibid.

$60 \quad$ Ibid.

61 Clark, Jarle. Personal Interview. Viken Prison, March 2016.

62 Martinez, Jenny. Personal Interview. Viken Prison, March 2016. 
Officers also attributed their struggle to balance dynamic security, built upon relations between inmates and officers, with their administrative duties to limited resources. The officers discussed feeling the pressure of a high work volume, and admitted to having a hard time prioritising their work in a way that satisfies their administrative duty requirement, as well as the expectations for interaction and relationship building with the inmates. Some officers also said their administrative duties separated them from the inmates more than they would like. During the interviews, the officers attributed this problem to the absence of sufficient staff to manage the workload. One officer expressed this clearly by saying, 'They want more [accomplished], but they cut the money and resources...'63

According to one officer, some officers have adopted what he described as a work ethic that is just enough to 'make the boss happy' and no more. For this reason, officer-inmate interactions have been limited. Using the issue of drugs and the demand on resources to combat it as an illustration, Officer Sam said, 'It's a cat and mouse chase for drugs; we lock them behind doors and [we do] not interact with them. That's what we are being told on many of the units (emphasis added)'. He also said, 'I think the more pressure you put on Correction Officers, the more pressure they'll put on the inmates... ${ }^{64}$ For another officer, the effect on inmates has been poignant: 'I can't do everything, so that means inmates have to wait longer than necessary and when the inmates have to wait they can get aggressive and tired of sitting here. This is a very slow system so it's a lot of waiting for the inmates. ${ }^{65}$

Speaking more candidly, another officer said, 'I think we need more employees. It's a [resource] question and everything. Some years ago we were much more than today and we are still being cut off. ${ }^{66}$ She then said, 'Inmates need to have this human connection (emphasis added), to be seen and listened to' ${ }^{67}$ This connection, she explained, is an opportunity for officers to lead by example so that inmates can see how to behave, and to learn more about social etiquette.

When discussing the impact limited capacity has had on inmates, the officers reported that the inmates' resources are currently insufficient and they do not have the same opportunities as before:

...Before, it was 10 officers working with 48 inmates. Now we're at five or six. Before, they could take inmates out to places like the cinema, fishing and do normal activities that people do outside, which I think is quite important. Now, it's not time for such things and that's part of the rehabilitation. We don't have people for it anymore and we

\footnotetext{
63 Sam Salomon Interview.

$64 \quad$ Ibid.

65 Landvik, Henry. Personal Interview. Viken Prison, March 2016.

66 Silje, Marte. Personal Interview. Viken Prison, March 2016.

$67 \quad$ Ibid.
} 
don't have the money for it, so people [who have been] sitting here for a long time would always tell me how it was before. ${ }^{68}$

Some officers believe that capacity related issues have also impacted inmates. For one officer, the issue of limited space has resulted in some inmates being moved to new wings prematurely - to make room for newer inmates - thus causing a situation where some inmates are placed in a wing with more freedoms and privileges that they cannot fully enjoy:

\begin{abstract}
...There are some people coming here and they start the sentence here, but it can be a while before they are even going on a permission (such as home leave, school or outside work). They even come before [their time] and I think it's too early... They see their pals going and coming daily and they have to sit for months to a year before they can do the same. ${ }^{69}$
\end{abstract}

Essentially, such inmates may be in a less restrictive wing, but find that they cannot participate in some of the same available programmes or activities as other inmates because they have not served enough of their sentence to qualify. Furthermore, while officers may perceive some inmates as displaying a lack of motivation, the behaviour may instead be a result of boredom or frustration in response to what they perceive as inattentiveness or apathy on the part of the officers. Conversely, inmates' perception of officers as 'unfriend$l y$ ' and uncaring may instead be a result of the officers' struggle to efficiently manage their workload and fulfil their obligations. In other words, while officers feel the strain of the administrative changes that compel them to rearrange their priorities (sometimes at the expense of inmates), inmates feel a sense of distrust towards officers, who are (to some degree) seen as unreliable. Finally, administrative, logistical and resourcing difficulties have also resulted in officers implementing a seemingly more static role in security in place of the traditionally dynamic role in security.

\title{
4.6 Unequal Treatment
}

The subject of unequal treatment highlighted a few specific areas: female inmates' inability to access rehabilitative programmes, foreign inmates' limited access to officer assistance, and bias and privilege regarding officer-inmate interactions.

Foreign inmates often complained that they've received the bare minimum of help while in prison. They said that they've often had to ask their Norwegian friends to request favours or to make inquiries on their behalf because that is the best way to get an officer to respond. Minimum assistance for foreign inmates includes food, clothing and other

\footnotetext{
68 Eva Wolff Interview.

69 Marte Silje Interview.
} 
basic services and activities as well as the services of a translator in important cases when officers cannot communicate with the inmates. If there are multiple inmates from the same foreign country, of which one speaks Norwegian, this person may be asked to act as a translator in some cases, to avoid acquiring a professional translator. In other cases, communication is often limited to the use of a picture book, which officers use to aid in communication.

For the officers who addressed this issue, their general sentiment was that Norwegian citizens are indeed the 'priority', whereas foreign inmates receive 'minimum' assistance. ${ }^{70}$ According to one officer, this is because foreign inmates are not considered as entitled to the same rehabilitation measures as Norwegian inmates; thus impacting some inmates' access to rehabilitative programmes and services. The presumption, here, is that minimum effort is needed because, unless they are legal residents, there is a small likelihood that foreign inmates will be released into Norwegian society. Explaining the issue of 'minimum' help, Officer Jenny said, 'we help them, but they don't have the same rights [as Norwegian inmates]. For example, [they don't get] help from NAV or [with] housing. They have the right to clothes but not a place to live or a job! ${ }^{71}$

With regard to the women, as explained above, the study did not include any female participants. However, many of the officers expressed the need for more female-specific programmes. One officer described female inmates at Viken Prison as 'the forgotten group in Kriminalomsorgen ${ }^{72}$ because of the lack of programmes available for them. The officer also said, 'They have for a long time [felt] like they are not a priority.73 The officers indicated that they are aware of this issue and intend to restart a female-specific programme, 'VINN', that was shut down years ago due to limited resources. ${ }^{74}$ The officers expressed optimism for this programme; only one officer was hesitant, stating that he was 'afraid it can be stopped' because of budgetary issues. ${ }^{75}$

In addition to the problems with foreign inmates and women, other inmates also complained about bias and privilege with respect to officer-inmate interaction. Compounding the issue of unequal treatment is the pressure inmates place on the more 'caring' or 'helpful' officers while trying to get answers related to their cases or needs. Many inmates described struggling to find an officer who they believe care. They voiced

Eva Wolff Interview

Jenny Martinez Interview

Ibid.

Henry Landvik Interview.

VINN is a conversation-based psychological programme that is focused on helping the inmates to master their lives and to leave a crime-related lifestyle behind. See further, Årsmelding for seksjon for fengselshelsetjenester, Klinikk for sikkerhetspsykiatri, Haukeland Universitetssykehus (2012) pp. 13.

75 Henry Landvik Interview. 
frustration when describing the stark differences in attitudes from officers on issues where they feel they should be unified. For example, inmates have said that some officers are lenient, whereas others are incredibly rigid to the point where it feels that the officer is 'using the uniform against' them. Some inmates went on to state that such officers often speak to them condescendingly-as if they are 'children' or 'idiots'and practice being rigid because they believe that means they are doing a 'good job'. Officer Sam offered a similar view, stating,

\footnotetext{
[with] the different officers, [there are] different rules [and] different consequences. They (the inmates) envy each other because one could do something and the other couldn't. One (officer) is nice to one (inmate) and not nice to the other (inmate), or one contact officer is nice and sweet and the other is strict. I think it's frustrating to inmates. ${ }^{76}$
}

In sum, although officers hold a common stance on the conceptualisation of rehabilitation, the data suggest that this stance may not be universally extended to all inmates; thus impacting some inmates' access to rehabilitative programmes and services. Women and non-Norwegian inmates have limited access to programmes and officer assistance, respectively, while other inmates complain of bias and officers' varying degrees of preference towards certain inmates.

\section{Discussion}

The study in Viken Prison provides reason for further discussion on several topics. First, it calls for discussion about how the conceptualisation of rehabilitation among inmates and officers relate to an adequate theory of rehabilitation, and to a successful realisation of rehabilitation strategies in prison. By looking at the way rehabilitation is currently understood, we begin to see how this impacts the inmates' and officers' attitude towards engaging in activities, programmes and services.

Officers and inmates, respectively, seemed to view rehabilitation in distinctly different ways. The officers' opinions of rehabilitation seemed closely integrated with their training, and reflected the legal view on rehabilitation, whereas the inmates' perspectives were more nuanced and based on their experience.

Both inmates and officers asserted that rehabilitation has a place and a function within the prison. Where they differed, though, is on what rehabilitation amounts to and for whom rehabilitation is meant for. Officers generally described rehabilitation as reducing the risk for new criminality and as such potentially relevant for all inmates. Many inmates 
instead primarily associated the term 'rehabilitation' with specific issues related to drugs, sexual assault or violence, and would often point to the prison-instituted programmes that are in place to address these issues. Essentially inmates view rehabilitation as relevant only for those inmates they perceive as being in need of specific treatment. Also of particular note is that some inmates, to some degree, appeared to associate the word 'rehabilitation' with 'abnormality', thus suggesting that the word carries some stigma. This leaves the question of whether some inmates use the prison's programmes to define rehabilitation, and thus its role in their lives, or that they have a problem with the term 'rehabilitation' specifically. ${ }^{77}$

Still, this disparity between the understanding of rehabilitation among those attempting to realise it and those to be 'rehabilitated' may hinder constructive work in prison. It also points to the perhaps always-present 'imbalance of power' between inmates and officers that may affect any attempt of rehabilitation in prison. ${ }^{78}$ Further research is needed, in order to fully understand the impact of the different views of rehabilitation on inmates and officers.

Another point of interest in this discussion was that some inmates expressed their views on rehabilitation in relation to personal autonomy and personal benefit, and felt that they had little say in or strategies for affecting their own rehabilitation. Seen in the light of the fact that some officers expressed that the participation in offered rehabilitation programmes had an impact on the inmates' progression to a less restrictive wing, this is problematic. It raises concerns because it relegates rehabilitation to a 'top-down' strategy that is in clear tension with the basic constitutional principles about respect for the individual. Participation in rehabilitation activities and programmes should be voluntary according to the law, and should therefore not impact the inmates in a way that may put pressure on them to participate against their will. Instead, interested inmates should be motivated to participate and have a clear aim of what they want to achieve from these programmes. ${ }^{79}$

In this regard, we may also look at rehabilitation as more than just the hope that an inmate-once released-will cease and desist from criminality. Because we know that the decision to desist and actualizing it are two very different things, we should not only consider the rehabilitative process as voluntary, but as a 'long-term abstinence' from crime.

77 Earlier studies have indicated that inmates may have trouble with the use of the term 'rehabilitation', see Shadd, Making Good. How Ex-convicts Reform and Rebuild Their Lives, (American Psychological Association 2001) p. 26.

78 For an important prison study on this topic, see Ugelvik, Fangenes Friheter: Makt og motstand $i$ et norsk fengsel (Universitetsforlaget 2011).

79 See Værøy, Andreson, and Mowinkel, The Likelihood of Successful Crime Prevention: Norwegian Detainees on Preventive Detention Views on Programmes and Services Organized and Provided by the Criminal Justice System, Psychiatry, Psychology and Law 18, no. 2 (2011) pp. 240-247. 
In so doing, the focus is shifted from an implied expectation of complete transition or change on the part of the inmate, to the 'maintenance' of crime-free behavior. ${ }^{80}$

Our study not only revealed conflicting views on rehabilitation, but also pointed to some key issues within Viken Prison concerning isolation, mental health problems, inmate drug use and resource scarcity. These issues may seriously affect the inmates motivation and ability to participate, and may also affect the prospects for successful rehabilitation more generally.

On the subject of inmate isolation, there is already conflict between the concepts of deprivation of liberty, and rehabilitation during the prison sentence. This becomes particularly manifest for those who are isolated in prison and are thereby-to a significant extent-excluded from the activities offered in prison. That unit One-A seems to be becoming a pure 'isolation' unit is deeply troubling in this regard, especially since inmates generally start serving their prison sentence in this unit. ${ }^{81}$ The increasing problem of mental health issues among the inmates makes this even more concerning. ${ }^{82}$ Mental health issues may prevent some inmates from moving to a less restrictive wing, thus impacting their ability to progress (to a less restrictive wing) over time. Generally, the design prison spaces should be considered to ensure that inmates have enough room for activities.

Conditions of care (i.e. positive prisoner-guard interaction or a 'caring approach' to inmates) ${ }^{83}$ are also important as they impact how inmates respond to rehabilitation initiatives.$^{84}$ However, given the rise in inmates with mental health related issues, there is also a need for specific specialised resources and education. Although there are psychiatric specialists available at Viken Prison, rules on confidentiality prevent medical staff from sharing patient information with officers, except for in a serious emergency. The length and nature of the training provided to prison officers in Viken Prison is quite

80 For a discussion on the concept of desistence, see Shadd 2001, pp. 19-35.

81 The use of isolation in Norwegian prisons more generally has been criticised, for instance, by the European Committee of the Prevention of Torture and Inhuman or Degrading Treatment or Punishment (CPT), see reports from visits available at: http://www.cpt.coe.int/en/visits.htm, (Accessed December 3, 2016). Recently the local court of Oslo also concluded that the prison regime around Anders Behring Breivik due to his isolation was a violation of ECHR article 3, see judgment TOSLO-2015-107496-3. The judgement has been appealed.

82 Regarding the scope of this problem, see Cramer, Forekomst av psykiske lidelser hos domfelte $i$ norske fengsler, Prosjektrapport fra kompetansesenter for sikkerhets, fengsels og rettspsykiatri, helse-region sør-øst, 2014-1.

83 Neumann, Imprisoning the Soul in Penal Exceptionalism? Nordic Prison Policy and Practice, (Routledge 2012) pp. 139-151.

${ }^{84}$ See Kjelsberg, Skoglund, and Rustad, Attitudes towards Prisoners, As Reported By Prison Inmates, Prison Employees and College Students, BMC Public Health 7, no. 1 (December 4, 2007) pp. 71-78. 
exceptional when compared to many other countries.$^{85}$ However, there are some reservations concerning the officers' ability to manage the rising number of inmates with mental health issues, while they, the officers, are steadily decreasing in numbers. The efforts that must still be made in this respect, certainly affect the possibilities of rehabilitative work for the inmates in general because of the demand on the physical and material resources of the prison.

Resources are also needed in the effort to combat inmate drug use in the prison. As officers work to abate the issue, their time is being spent on static security rather than dynamic security, which was implemented with rehabilitation in mind. It is worth noting that a significant number of the inmates have a drug problem. ${ }^{86}$ A survey from 2004 shows that among 260 inmates in 37 different prisons, almost $60 \%$ had a drug-problem when starting their sentence. ${ }^{87}$ Statistics also show that a significant number of all inmates in Norwegian prisons are serving a sentence for drug-related crimes, and that this group of inmates seem to have a high recidivism rate. ${ }^{88}$ In addition, this group of inmates often serve quite short prison sentences, and may end up being released before having an opportunity to fully utilise the programmes or services available. In the end, we must consider whether a prison sentence is actually an adequate reaction at all for this problem. Perhaps a more suitable course of action would be to focus on processing drug related cases using an alternative route such as a drug court. ${ }^{89}$

Resource scarcity in Viken Prison also seems to be the primary explanation for the problematic aspects of the unequal administration of rehabilitative programmes between men and women. Still, it is unacceptable for women not to have an equivalent access to programmes and activities as the male inmates in general, and this problem must be addressed. ${ }^{90}$ Even though most inmates are men, women must also be treated equally when

85 Prison officers in Norway undergo a two-year education programme at the Norwegian Correction Service Staff Academy (KRUS), where they are taught various subjects such as sentencing law and ethics. For more information see, http://www.krus.no/progress-of-thestudies.5275524-295832.html?showtipform=2. (Accessed December 1 2016)

86 For a study on this matter, see Lobmaier et al., Substance Use and Problem Awareness among Drug-involved in Norway, Journal of Substance Use (2013) pp. 211-220.

87 See Friestad and Hansen, Levekår blant innsatte, Fafo 2004, pp. 58-67. For a more recent survey, see also Revold, Innsattes levevilkår før, under og etter soning, Statistisk sentralbyrå, rapport 2015/47 pp. 49-57.

88 See annual statistics from the Correction Services, available at http://www.kriminalomsorgen. no/statistikk-og-noekkeltall.237902.no.html. See also statistics regarding the use of the prison sentence, available at www.ssb.no. (Accessed December 1, 2016)

89 A positive development is that Norway has permanently established a drug-programme with court control as an alternative to prison. See https://www.regjeringen.no/no/aktuelt/ landsdekkende-narkotikaprogram/id2475580/. (Accessed December 1, 2016).

90 For a discussion on this problem in the UK, see Currie, Women in Prison: A Forgotten Population, Internet Journal of Criminology (2012) pp. 1-30. 
it comes to rehabilitation. The problems also call for further research on whether women have a specific situation and need in prison.

In light of today's highly international and organised criminality, some officers' understanding of the needs of foreign inmates can become problematic. Under constitutional law and human rights law, Norway is obliged to ensure that foreign inmates are not discriminated against. When serving a sentence under the same conditions in a Norwegian prison, Norwegian and non-Norwegian inmates must always be treated equally when it comes to the realisation of their rights. Another matter for consideration is whether there may be a better alternative for foreign inmates whereby they serve their sentence in their own country.

Rehabilitation in practice is challenging. It requires more than adequate legal principles. It also requires appropriate attitudes and education among the prison staff, and an 'adequate prison population', meaning that we may also rethink the current scope of the criminal law with regard to drug crimes. Perhaps it may also require many other considerations than those we have emphasised. But in the end, it requires resources, and political and administrative will to invest in the prison and, most of all, in the inmates, and thus put action to the beliefs that are expressed in law. 